\title{
39. ROCK MAGNETISM AND PALEOMAGNETISM OF BASALTS DRILLED DURING DEEP SEA DRILLING PROJECT LEG 65 ${ }^{1}$
}

\author{
D. M. Pechersky and L. V. Tikhonov, Earth Physics Institute of the USSR Academy of Sciences, Moscow, USSR \\ and \\ B. P. Zolotarev, Geological Institute of the USSR Academy of Sciences, Moscow, USSR
}

\section{INTRODUCTION}

We investigated the magnetic and paleomagnetic properties of 77 basalt samples from Holes $482,482 \mathrm{C}, 482 \mathrm{D}$, $483,483 \mathrm{~B}, 485$, and $485 \mathrm{~A}$ in order to study the structure and development of the ocean's crust. During the course of this study, we measured the natural remanent magnetization, $J_{n}$, and its stability in an alternating magnetic field; the magnetic susceptibility, $\chi$; the saturation magnetization, $J_{s}$; the saturation remanent magnetization, $J_{r s}$; the coercivity of maximum remanence, $H_{C R}$; and the median destructive fields $\mathrm{MDF}_{n}$ (for $J_{n}$ ) and $\mathrm{MDF}_{s}$ for $J_{r s}$. A thermomagnetic analysis for $J_{s}$ and $J_{r s}$ was also performed; these latter measurements were made on the same samples.

The magnetic studies were carried out on cubic samples with $0.9-\mathrm{cm}$ sides in the geomagnetic field laboratory of the Earth Physics Institute of the USSR Academy of Sciences in Moscow. Saturation magnetization and thermodemagnetization measurements were made using a vibration magnetometer in a 2500 Oe d.c. field. The saturation remanent magnetization and $J_{r s}$ thermodemagnetization measurements were conducted with a thermomagnetometer (Burakov, 1977). The magnitude and direction of magnetization were determined using a spinner magnetometer. The samples were demagnetized in an alternating field to $600-700 \mathrm{Oe}$, although 100-200 Oe was usually sufficient for determining the stable direction. Each sample was cleaned in two steps of three increments. Since the samples were only partially oriented (the azimuth could not be determined), only the inclination, $I$, was considered in paleomagnetic studies of the core. Magnetic susceptibility $\chi$ was measured using the technique described by Skovorodkin et al. (1970).

The results of the magnetic measurements are presented in Table 1 . Table 2 shows the average values for each site and hole and the average value for fresh basalts $\left(T_{\mathrm{C}} \leq 200^{\circ} \mathrm{C}\right)$.

\section{ROCK MAGNETISM}

The basalts from Sites 482 and 485 are predominantly massive basalts. This was reflected in the relatively low values of $J_{r s} / J_{s}, H_{C R}$, MDF, and $J_{n}$ and in the high values of $J_{s}$ and $\chi$ (Tables 1,2 ), which are characteristic

\footnotetext{
${ }^{1}$ Lewis, B. T. R., Robinson, P., et al., Init. Repts. DSDP, 65: Washington (U.S. Govt. Printing Office).
}

of fresh and slightly altered massive basalts but not pillow basalts (Ade-Hall et al., 1976; Hall and Ryall, 1977b; Johnson and Hall, 1978; Pechersky et al., 1979).

The average Curie points $\left(T_{C}\right)$ of the basalts from Sites 482 and $483\left(223^{\circ}\right.$ and $210^{\circ}$, respectively) are consistent with, or slightly higher than, the values appropriate for typical primary titanomagnetite observed in ocean basalts $\left(150^{\circ}\right.$ for $\chi_{\mathrm{av} .}=0.62$; Johnson, 1979). The somewhat higher average $T_{\mathrm{C}}$ values appear to be related to oxidation of primary titanomagnetite. In most ocean basalts, this results in a decrease of $J_{n}$ and an increase in $H_{C R}, \mathrm{MDF}$, and $T_{\mathrm{C}}$. As can be seen in Table 2, however, this tendency is not followed in the case of the massive basalts from Site 483 , where $J_{n}$ and $J_{s}$ increase rather than decrease with alteration.

Most ocean basalts display an increase in saturation magnetization and the appearance of a mineral similar to magnetite after heating to $500-600^{\circ} \mathrm{C}$. As a result, the ratio of saturation magnetization after heating to that before, $J_{s t} / J_{s}$, is usually greater than 1 . Although a small number of pillow basalts from Site 483 show this behavior (e.g., Sample 483B-31-1, $115 \mathrm{~cm}$ ), this ratio is usually less than 1 for the basalts drilled on Leg 65, and subsequent heating curves are generally shifted to the left (Fig. 1),

The distribution of Curie temperatures for the basalts from Site 483 shows a single peak with a mode of $200^{\circ} \mathrm{C}$ and a tail to the right toward higher temperatures (Fig. 2). These basalts are the oldest of those studied on Leg 65 and include many pillow basalts. The distribution of Curie temperatures for the basalts from Site 482 and especially from Hole 485A (Fig. 2) is different, however. In the former, samples with Curie temperatures of $350^{\circ}-550^{\circ}$ are present but uncommon, while in the latter, samples with temperatures greater than $350^{\circ}$ are common and the distribution is obviously multimodal. Samples with high Curie temperatures are usually observed among altered rocks.

When judged on the basis of magnetic properties, the basalts from Hole $485 \mathrm{~A}$ can be divided into four units (Table 3). In the upper magnetic unit, the basalts are fresh and have an average Curie temperature of $218^{\circ} \mathrm{C}$, whereas Units 2 through 4 are slightly altered and display an average Curie temperature exceeding $300^{\circ} \mathrm{C}$ and numerous values between $350^{\circ}$ and $500^{\circ} \mathrm{C}$.

The low-temperature oxidation of titanomagnetite in ocean basalts usually produces a single oxidation phase, a decrease in $J_{s}$, and an increase in $H_{C R}, \mathrm{MDF}$, and $T_{\mathrm{C}}$. 
Table 1. Magnetic properties of basalt from Sites 482, 483, and 485 .

\begin{tabular}{|c|c|c|c|c|c|c|c|c|c|c|c|c|c|c|c|}
\hline $\begin{array}{c}\text { Sample } \\
\text { (interval in } \mathrm{cm} \text { ) }\end{array}$ & $\begin{array}{l}\text { Rock } \\
\text { Type }\end{array}$ & $\left(\times 10^{-3} 3^{\chi}\right.$ gauss $\left./ O e\right)$ & $\begin{array}{c}J_{n} \\
\left(\times 10^{-3} \text { gauss) }\right.\end{array}$ & $Q_{n}$ & $\begin{array}{l}I_{n} \\
\left({ }^{\circ}\right)\end{array}$ & $\begin{array}{l}D_{n} \\
\left({ }^{\circ}\right)\end{array}$ & $\begin{array}{c}I_{\text {stable }} \\
\left({ }^{\circ}\right)\end{array}$ & $\begin{array}{c}D_{\text {stable }} \\
\left({ }^{\circ}\right)\end{array}$ & $\begin{array}{l}\mathrm{MDF}_{n} \\
(\mathrm{Oe})\end{array}$ & $\begin{array}{l}\mathrm{MDF}_{S} \\
(\mathrm{Oe})\end{array}$ & $\begin{array}{l}\mathrm{H}_{C R} \\
(\mathrm{Oe})\end{array}$ & $\underset{(\mathrm{emu} / \mathrm{g})}{J_{S}}$ & $J_{r s} / J_{s}$ & $J_{s t} / J_{s}$ & $\begin{array}{l}T_{\mathrm{C}} \\
\left({ }^{\circ} \mathrm{C}\right)\end{array}$ \\
\hline \multicolumn{16}{|l|}{ Hole 482B } \\
\hline $11-1,40-42$ & Fresh massive aphyric basalt & 1.47 & 5.0 & 6.8 & 53 & 67 & 30 & 78 & 47 & 25 & 55 & 1.42 & 0.08 & 0.85 & 190 \\
\hline $12-3,17-19$ & Fresh massive aphyric basalt & 1.3 & 6.3 & 9.7 & 64 & 180 & 32 & 185 & 48 & 26 & 55 & 1.10 & 0.10 & 0.92 & 160 \\
\hline $14-1,21-23$ & Fresh massive aphyric basalt & 1.4 & 5.8 & 8.3 & 73 & 184 & 50 & 180 & 55 & - & 74 & 1.26 & 0.08 & 0.93 & 230 \\
\hline $15-2,131-133$ & Fresh massive aphyric basalt & 1.38 & 3.6 & 5.2 & 31 & 325 & 24 & 308 & 42 & - & 73 & 1.47 & 0.075 & 0.92 & 230 \\
\hline $15-3,42-44$ & Fresh massive porphyritic basalt & 1.2 & 3.9 & 6.5 & 40 & 176 & 21 & 171 & $\bar{n}$ & 27 & 66 & 1.22 & 0.12 & 0.85 & 190 \\
\hline $16-4,29-31$ & Fresh massive porphyritic basalt & 1.39 & 2.3 & 3.3 & 75 & 218 & 59 & 223 & 22 & 28 & 60 & 1.30 & 0.065 & 0.79 & 230 \\
\hline $18-1,136-138$ & Fresh massive porphyritic basalt & 1.08 & 6.2 & 11.5 & 55 & 69 & 23 & 69 & - & 30 & 67 & 1.09 & 0.11 & 0.92 & $210(90), 350$ \\
\hline $20-2,35-37$ & Fresh massive porphyritic basalt & - & 5.0 & - & 37 & 83 & 37 & 82 & 70 & 29 & 77 & 1.39 & 0.095 & 0.82 & 285 \\
\hline $21-1,136-138$ & Fresh massive porphyritic basalt & 1.2 & 5.3 & 8.8 & 52 & 318 & 44 & 324 & - & - & 66 & 1.30 & 0.1 & 0.8 & 240 \\
\hline $21-3,81-83$ & Fresh massive porphyritic basalt & 1.2 & 13.6 & 22.7 & 58 & 109 & 47 & 119 & 42 & 31 & 67 & 1.30 & 0.13 & 0.74 & 250 \\
\hline $22-1,73-75$ & Fresh massive porphyritic basalt & - & 7.5 & - & 65 & 120 & 40 & 149 & - & - & 60 & 1.20 & 0.1 & 0.73 & 230 \\
\hline $22-3,122-124$ & Fresh massive porphyritic basalt & 1.08 & 2.3 & 4.3 & 53 & 156 & 36 & 156 & 36 & - & 56 & 1.1 & 0.07 & 0.84 & 190 \\
\hline $24-3,21-23$ & Fresh massive aphyric basalt & 1.75 & 3.8 & 4.3 & 70 & 176 & 42 & 157 & - & - & 63 & 2.0 & 0.055 & 0.86 & 270 \\
\hline \multicolumn{16}{|l|}{ Hole $482 \mathrm{C}$} \\
\hline $10-1,118-120$ & Altered massive aphyric basalt & - & 4.0 & - & 38 & 7 & 23 & 9 & 42 & - & 62 & 2.15 & 0.055 & 0.65 & 450 \\
\hline $11-3,109-111$ & $\begin{array}{l}\text { Massive aphyric basalt, } \\
\text { slightly altered }\end{array}$ & 1.54 & 2.5 & 3.2 & 41 & 9 & 37 & 17 & 45 & - & 58 & 1.4 & 0.04 & 0.82 & $200(70), 340$ \\
\hline $11-4,42-44$ & Fresh massive aphyric basalt & 1.3 & 4.7 & 7.2 & 40 & 31 & 36 & 22 & 64 & - & 74 & 1.37 & 0.05 & 0.92 & $240(80), 350$ \\
\hline $12-1,31-33$ & Fresh massive porphyritic basalt & 1.22 & 2.5 & 4.1 & 24 & 317 & 7 & 326 & 50 & 38 & 63 & 1.5 & 0.065 & 0.88 & 220 \\
\hline $13-2,60-62$ & Fresh massive porphyritic basalt & - & 3.9 & - & 34 & 312 & 10 & 292 & 130 & 65 & 170 & 2.35 & 0.085 & 0.94 & $300(10), 510$ \\
\hline $14-4,14-16$ & Fresh massive porphyritic basalt & 1:44 & 2.4 & 3.3 & 20 & 8 & 6 & 5 & 30 & - & 62 & 1.48 & 0.06 & 0.86 & $220(90), 350$ \\
\hline $15-1,66-68$ & Fresh massive porphyritic basalt & 1.3 & 1.5 & 2.3 & 14 & 206 & 10 & 204 & 50 & 33 & 66 & 1.3 & 0.065 & 0.81 & 230 \\
\hline $15-4,139-141$ & Fresh massive porphyritic basalt? & - & 2.8 & - & 31 & 77 & 5 & 74 & 50 & 34 & 71 & 1.17 & 0.1 & 0.78 & 250 \\
\hline \multicolumn{16}{|l|}{ Hole 482D } \\
\hline $9-1,115-117$ & Altered massive aphyric basalt & 1.01 & 7.3 & 14.5 & 30 & 333 & 38 & 328 & 520 & - & 514 & 1.67 & 0.27 & 0.73 & 540 \\
\hline $10-2,85-87$ & Fresh massive aphyric basalt & - & 8.4 & - & 16 & 64 & 32 & 69 & 50 & - & 44 & 1.67 & 0.045 & 0.74 & $300 ?(20), 360$ \\
\hline $10-3,47-49$ & $\begin{array}{l}\text { Slightly altered fresh massive } \\
\text { aphyric basalt }\end{array}$ & 1.54 & 4.1 & 5.3 & 24 & 180 & 23 & 170 & 65 & - & 75 & 2.14 & 0.05 & 0.77 & 370 \\
\hline $11-2,45-47$ & Fresh massive aphyric basalt & 0.87 & 10.5 & 24.1 & 12 & 69 & 20 & 84 & 60 & 43 & 85 & 1.2 & 0.14 & 0.85 & $230(70), 380$ \\
\hline $12-3,130-132$ & Fresh pillowed to massive basalt & 1.17 & 1.4 & 2.4 & -17 & 168 & 9 & 166 & 70 & 32 & 64 & 1.4 & 0.073 & 0.85 & \\
\hline $13-1,52-54$ & $\begin{array}{l}\text { Fresh pillowed to massive basalt; } \\
\text { near glassy margin of flow }\end{array}$ & 1.27 & 1.3 & 2.0 & 20 & 244 & 13 & 237 & 70 & 50 & 109 & 1.45 & 0.08 & 0.75 & 320 \\
\hline \multicolumn{16}{|l|}{ Hole $482 \mathrm{~F}$} \\
\hline $5-1 ; 67-69$ & $\begin{array}{l}\text { Massive porphyritic basalt, } \\
\text { slightly altered }\end{array}$ & - & 14.0 & - & 29 & - & 28 & - & 45 & 30 & 65 & 1.03 & 0.15 & 1.0 & 210 \\
\hline \multicolumn{16}{|l|}{ Hole 483} \\
\hline $14-1,102-104$ & Altered massive aphyric basalt & 0.98 & 3.0 & 6.1 & 20 & 160 & 18 & 156 & 95 & - & 87 & 0.94 & 0.095 & 0.98 & 240 \\
\hline $15-1,110-112$ & Fresh massive porphyritic basalt & 1.16 & 1.5 & 2.6 & -30 & 52 & -20 & 53 & 70 & - & 62 & 1.04 & 0.055 & 0.91 & $200(90), 370$ \\
\hline $16-1,99-101$ & $\begin{array}{l}\text { Slightly altered massive } \\
\text { porphyritic basalt }\end{array}$ & 1.23 & 3.3 & 5.4 & -39 & 338 & -42 & 344 & 55 & 37 & 72 & 1.26 & 0.073 & 0.95 & 230 \\
\hline $17-2,108-110$ & Fresh massive aphyric basalt & 0.67 & 2.4 & 7.2 & -31 & 220 & -38 & 213 & 90 & 50 & 115 & 0.81 & 0.07 & 0.97 & 225 \\
\hline $20-1,46-48$ & Fresh porphyritic pillow basalt & 0.7 & 13.9 & 39.7 & -36 & 339 & -38 & 333 & 80 & - & 89 & 0.86 & 0.21 & 0.95 & 160 \\
\hline $21-2,92-94$ & Fresh porphyritic pillow basalt & $0: 92$ & 15.6 & 33.9 & -32 & 243 & -40 & 245 & 68 & 40 & 71 & 0.81 & 0.23 & 1.05 & 160 \\
\hline $22-4,110-112$ & $\begin{array}{l}\text { Slightly altered, porphyritic } \\
\text { pillow basalt }\end{array}$ & 1.1 & 6.2 & 11.3 & -40 & 86 & -45 & 84 & 68 & 38 & 84 & 1.28 & 0.11 & 0.93 & 230 \\
\hline $23-2,86-88$ & Fresh porphyritic pillow basalt & 0.86 & 17.2 & 40.0 & -37 & 337 & -41 & 335 & 62 & - & 81 & 1.18 & 0.17 & 0.97 & 200 \\
\hline $25-2,45-47$ & $\begin{array}{l}\text { Slightly altered, massive } \\
\text { porphyritic basalt }\end{array}$ & 1.42 & 5.5 & 7.7 & -16 & 314 & -32 & 313 & - & - & 78 & 1.42 & 0.075 & 0.94 & $180(80), 350$ \\
\hline $26-2,79-81$ & Fresh porphyritic pillow basalt? & 1.1 & 14.8 & 26.9 & -30 & 215 & -30 & 217 & 68 & 40 & 84 & 1.52 & 0.12 & 0.96 & 240 \\
\hline $.26-3,68-70$ & Fresh massive porphyritic basalt? & - & 8.7 & - & -28 & 329 & -30 & 324 & 65 & 44 & 76 & 1.33 & 0.09 & 0.89 & $240(75), 380$ \\
\hline \multicolumn{16}{|l|}{ Hole 483B } \\
\hline $4-5,5-7$ & Fresh massive aphyric basalt & 1.19 & 1.06 & 1.8 & -11 & 86 & -30 & 80 & - & - & - & 0.83 & - & 0.95 & 200 \\
\hline $7-2,31-33$ & Fresh massive porphyritic basalt & 1.52 & 1.2 & 1.6 & 22 & 4 & -35 & 2 & - & 22 & 46 & 0.9 & 0.05 & 0.94 & $180(80), 310$ \\
\hline
\end{tabular}




\begin{tabular}{|c|c|c|c|c|c|c|c|c|c|c|c|c|c|c|c|}
\hline $8-3,44-46$ & $\begin{array}{l}\text { Slightly altered massive } \\
\text { aphyric basalt }\end{array}$ & 0.72 & 2.5 & 7.0 & -2 & 20 & -39 & 47 & 33 & 41 & 97 & 0.78 & 0.065 & 0.95 & $340(70), 460$ \\
\hline $12-1,72-74$ & $\begin{array}{l}\text { Slightly altered porphyritic } \\
\text { pillow basalt }\end{array}$ & - & 11.4 & - & -11 & 21 & -9 & 17 & 135 & - & 106 & 0.88 & 0.26 & 0.91 & 250 \\
\hline $13-3,84-86$ & $\begin{array}{l}\text { Slightly altered porphyritic } \\
\text { pillow basalt }\end{array}$ & 1.24 & 8.2 & 13.2 & -19 & 35 & -40 & 30 & - & - & 66 & 1.09 & 0.13 & 0.91 & $200(90), 330$ \\
\hline $17-1,124-126$ & $\begin{array}{l}\text { Slightly altered porphyritic } \\
\text { pillow basalt }\end{array}$ & 1.09 & 10.0 & 18.3 & -36 & 60 & -43 & 62 & 80 & 42 & 83 & 1.08 & 0.12 & 1.0 & 200 \\
\hline $19-2,12-14$ & $\begin{array}{l}\text { Slightly altered massive } \\
\text { porphyritic basalt }\end{array}$ & 1.23 & 8.2 & 13.3 & -24 & 262 & -31 & 263 & 80 & 37 & 76 & 1.42 & 0.09 & 0.92 & 210 \\
\hline $22-2,5-7$ & Altered porphyritic pillow basalt & 0.5 & 17.9 & 71.6 & -12 & 237 & -11 & 237 & 105 & $\overline{-}$ & 116 & 0.99 & 0.26 & 1.0 & 190 \\
\hline $23-2,112-114$ & $\begin{array}{l}\text { Slightly altered porphyritic } \\
\text { pillow basalt }\end{array}$ & 0.71 & 7.5 & 21.1 & 1 & 113 & -9 & 114 & 63 & 43 & 104 & 1.04 & 0.115 & 1.0 & 230 \\
\hline $25-1,134-136$ & $\begin{array}{l}\text { Slightly altered massive } \\
\text { porphyritic basalt }\end{array}$ & 1.19 & 2.0 & 3.4 & 27 & 270 & -20 & 260 & - & - & 63 & 1.38 & 0.085 & 0.96 & 230 \\
\hline $27-2,25-27$ & Fresh massive aphyric basalt? & - & 3.3 & - & 12 & 127 & -14 & 135 & 75 & 44 & 93 & 1.25 & 0.093 & 0.83 & 280 \\
\hline $27-3,6-8$ & Fresh massive porphyritic basalt? & 1.46 & 9.1 & 12.5 & -29 & 259 & -17 & 257 & - & - & 70 & 1.24 & 0.07 & 0.87 & 210 \\
\hline $30-1,114-116$ & $\begin{array}{l}\text { Slightly altered porphyritic } \\
\text { pillow basalt }\end{array}$ & 0.62 & 5.2 & 16.8 & -15 & 254 & -14 & 248 & 103 & - & 135 & 0.99 & 0.27 & 1.25 & 265 \\
\hline $32-1,115-117$ & Altered porphyritic pillow basalt & - & 2.7 & - & -36 & 288 & -17 & 280 & 95 & 50 & 102 & 0.94 & 0.24 & 1.3 & 290 \\
\hline \multicolumn{16}{|l|}{ Hole $483 \mathrm{C}$} \\
\hline $4-3,33-35$ & $\begin{array}{l}\text { Slightly altered massive } \\
\text { aphyric basalt }\end{array}$ & - & 1.5 & - & 10 & 77 & -10 & 90 & - & - & 89 & 1.12 & 0.08 & 0.96 & $220(80), 380$ \\
\hline $4-4,73-75$ & Fresh massive aphyric basalt & - & & \multicolumn{5}{|c|}{ unstable } & - & 26 & 60 & 1.16 & 0.04 & 0.96 & $200(85), 390$ \\
\hline \multicolumn{16}{|l|}{ Hole 485A } \\
\hline $12-1,36-38$ & Fresh massive porphyritic basalt & 1.25 & 7.6 & 12.2 & 24 & 74 & 24 & 73 & 40 & 37 & 63 & 1.07 & 0.155 & 1.06 & 180 \\
\hline $13-1,64-68$ & Massive aphyric basalt & 1.44 & 4.0 & 5.6 & 29 & 263 & 37 & 256 & 50 & - & 70 & 1.28 & 0.11 & 1.02 & 180 \\
\hline $14-1,40-42$ & Fresh massive porphyritic basalt & 1.45 & 4.2 & 5.8 & 33 & 46 & 46 & 49 & 46 & 37 & 66 & 1.29 & 0.11 & 1.0 & 180 \\
\hline $17-1,43-45$ & Fresh massive aphyric basalt & 1.27 & 4.9 & 7.7 & 27 & 262 & 32 & 260 & & 63 & 128 & 1.58 & 0.095 & 0.86 & $260(60), 520$ \\
\hline $23-2,76-78$ & Fresh massive aphyric basalt? & 1.87 & 3.1 & 3.3 & 58 & 219 & 46 & 180 & 52 & - & 70 & 1.37 & 0.07 & 0.9 & $240(80), 380$ \\
\hline $24-2,122-124$ & Fresh massive porphyritic basalt & 1.4 & 2.4 & 3.4 & 48 & 214 & 46 & 205 & 73 & - & 75 & 1.55 & 0.06 & 0.9 & $230(80), 350$ \\
\hline $25-1,108-110$ & Fresh massive porphyritic basalt & - & 3.7 & - & 30 & 73 & 46 & 73 & 60 & 40 & 72 & 1.71 & 0.055 & 0.91 & $230(70), 380$ \\
\hline $23-3,102-104$ & Fresh massive porphyritic basalt & 1.44 & 5.8 & 8.0 & 49 & 334 & 46 & 336 & 65 & 40 & 78 & 1.88 & 0.07 & 0.9 & $210(75), 340$ \\
\hline $29-1,54-56$ & Fresh massive porphyritic basalt? & 0.56 & 4.0 & 14.3 & 20 & 300 & 22 & 301 & 160 & - & 192 & 0.99 & 0.093 & 0.88 & 500 \\
\hline $30-1,144-146$ & Altered massive aphyric basalt & 1.55 & 7.0 & 9.0 & 18 & 40 & 25 & 39 & 120 & 54 & 122 & 2.0 & 0.083 & 0.84 & $280(15), 500$ \\
\hline $30-2,139-141$ & $\begin{array}{l}\text { Slightly altered massive } \\
\text { aphyric basalt }\end{array}$ & 0.82 & 3.0 & 7.3 & 10 & 320 & 17 & 320 & 60 & - & 95 & 0.82 & 0.13 & 1.16 & 380 \\
\hline $31-1,94-96$ & $\begin{array}{l}\text { Slightly altered massive } \\
\text { aphyric basalt }\end{array}$ & - & 2.2 & - & 9 & 114 & 21 & 115 & 77 & 46 & 100 & 1.5 & 0.04 & 0.9 & $365(50), 540$ \\
\hline $32-1,82-84$ & $\begin{array}{l}\text { Slightly altered massive } \\
\text { aphyric basalt }\end{array}$ & 0.92 & 2.0 & 4.4 & 22 & 48 & 18 & 56 & 130 & - & 120 & 0.43 & 0.135 & 0.93 & 450 \\
\hline $32-4,58-60$ & $\begin{array}{l}\text { Slightly altered massive } \\
\text { aphyric basalt }\end{array}$ & - & 3.4 & - & 17 & 6 & 34 & 6 & - & - & 125 & 2.06 & 0.045 & 0.87 & 500 \\
\hline $33-2,35-37$ & $\begin{array}{l}\text { Slightly altered massive } \\
\text { aphyric basalt }\end{array}$ & - & 8.2 & - & 43 & 68 & 45 & 67 & - & 65 & 145 & 1.9 & 0.09 & 0.9 & 480 \\
\hline $33-2,45-47$ & $\begin{array}{l}\text { Slightly altered massive } \\
\text { aphyric basalt }\end{array}$ & 1.48 & 0.7 & 1.0 & 12 & 284 & 14 & 273 & 85 & 53 & 156 & 1.71 & 0.06 & 0.9 & 480 \\
\hline $34-2,60-62$ & $\begin{array}{l}\text { Slightly altered massive } \\
\text { aphyric basalt }\end{array}$ & - & 3.9 & - & 48 & 86 & 36 & 90 & 30 & 23 & 58 & 1.4 & 0.055 & 0.87 & $260(70), 400$ \\
\hline $35-1,50-52$ & $\begin{array}{l}\text { Slightly altered massive } \\
\text { aphyric basalt }\end{array}$ & 1.61 & 3.4 & 4.2 & 14 & 56 & 26 & 51 & 60 & 22 & 60 & 1.19 & 0.06 & 0.88 & $170(85), 370$ \\
\hline $35-5,105-107$ & $\begin{array}{l}\text { Slightly altered massive } \\
\text { aphyric basalt }\end{array}$ & 1.5 & 6.1 & 8.1 & 20 & 259 & 42 & 230 & 30 & - & 56 & 1.33 & 0.06 & 0.85 & 240 \\
\hline $38-2,94-96$ & $\begin{array}{l}\text { Slightly altered massive } \\
\text { aphyric basalt }\end{array}$ & 1.15 & 0.8 & 1.4 & 29 & 126 & -46 & 153 & 23 & 47 & 107. & 1.42 & 0.085 & 0.87 & 380 \\
\hline $39-3,41-43$ & $\begin{array}{l}\text { Slightly altered massive } \\
\text { aphyric basalt }\end{array}$ & 1.44 & 0.8 & 1.1 & 53 & 170 & -37 & 253 & - & - & 60 & 1.38 & 0.1 & 0.86 & 290 \\
\hline $39-4,62-64$ & $\begin{array}{l}\text { Slightly altered massive } \\
\text { aphyric basalt }\end{array}$ & - & 0.7 & - & 10 & 195 & -36 & 188 & - & 39 & 69 & 1.29 & 0.1 & 0.8 & $270(90), 380$ \\
\hline
\end{tabular}

Note: $\chi=$ magnetic susceptibility; $J_{n}=$ intensity of natural remanent magnetization; Koenigsberger ratio, $Q_{n}=J_{n} / 0.5 x ; I_{n}, D_{n}=$ inclination and relative declination of natural remanent magnetization; $I_{\text {stable, }}$, $D_{\text {stable }}=$ inclination and relative declination of remanent magnetization after demagnetization; $\mathrm{MDF} n, \mathrm{MDF}$
maximum remanence the lower Curie point; $T_{\mathrm{C}}=$ Curie temperature. 
Table 2. Average magnetic properties of basalts from Sites 482,483 , and 485 .

\begin{tabular}{|c|c|c|c|c|c|c|c|c|c|c|c|c|c|c|}
\hline Location & Rocks & $N$ & $\begin{array}{c}J_{n} \\
\left(\times 10^{-3} \text { gauss }\right)\end{array}$ & $\left(\times 10^{-3^{2}} \stackrel{\chi}{\text { gauss } / O e)}\right.$ & $Q_{n}$ & $\begin{array}{l}I_{n} \\
\left({ }^{\circ}\right)\end{array}$ & $\begin{array}{c}I_{\text {stable }} \\
\left({ }^{\circ}\right)\end{array}$ & $\begin{array}{c}\mathrm{MDF}_{n} \\
(\mathrm{Oe})\end{array}$ & $\begin{array}{c}\mathrm{MDF}_{S} \\
(\mathrm{Oe})\end{array}$ & $\begin{array}{c}H_{C R} \\
(\mathrm{Oe})\end{array}$ & $J_{S}$ & $J_{r s} / J_{S}$ & $J_{S t} / J_{S}$ & $\begin{array}{l}T_{\mathrm{C}} \\
\left({ }^{\circ} \mathrm{C}\right)\end{array}$ \\
\hline \multirow[t]{2}{*}{ Hole 482B } & All basalts & 13 & 5.4 & 1.31 & 8.3 & 53 & 39 & 45 & 28 & 65 & 1.32 & 0.09 & 0.84 & 223 \\
\hline & & & 2.92 & 0.2 & 5.4 & 14 & 12 & $14(8)$ & $2(7)$ & 7 & 0.24 & & & 35 \\
\hline \multirow{2}{*}{ Hole $482 \mathrm{C}$} & All bảsalts & 8 & 3.04 & 1.36 & 4.0 & 28 & 16 & 58 & 42 & 78 & 1.59 & 0.065 & 0.83 & 290 \\
\hline & & & 1.1 & 0.13 & 1.9 & 12 & 14 & 31 & $15(4)$ & 37 & 0.42 & & & 119 \\
\hline \multirow[t]{2}{*}{ Hole 482D } & All basalts & 6 & 5.5 & 1.11 & 9.7 & 20 & 22 & 63 & 42 & 75 & 1.59 & 0.078 & 0.78 & 343 \\
\hline & & & 3.8 & 0.26 & 9.5 & 7 & 11 & 8 & (3) & 24 & 0.32 & $\cdot$ & & 112 \\
\hline Site 482 & All basalts & 28 & 5.07 & 1.29 & 7.6 & - & - & 54 & 35 & 71 & 1.44 & 0.08 & 0.83 & 260 \\
\hline Site 482 & All fresh basalts & 5 & 4.0 & 1.32 & 6.1 & - & 34 & 44 & 26 & 57 & 1.25 & 0.08 & 0.86 & 185 \\
\hline \multirow[t]{3}{*}{ Hole 483} & All basalts & 11 & 8.4 & 1.04 & 18.1 & -33 & -36 & 72 & 42 & 82 & 1.13 & 0.12 & 0.95 & 210 \\
\hline & & & 5.9 & 0.24 & 15.2 & 5 & 8 & $12(7)$ & $5(6)$ & 13 & 0.25 & & & 31 \\
\hline & Pillow basalts & 5 & & & & -39 & & & & & & & & \\
\hline \multirow[t]{2}{*}{ Hole 483B } & All basalts & 15 & 6.1 & 1.0 & 16.4 & -15 & -19 & 85 & 38 & 87 & 1.07 & 0.14 & 0.98 & 230 \\
\hline & & & 4.8 & 0.35 & 19.5 & 18 & 14 & $29(9)$ & $9(7)$ & 24 & 0.18 & & & 44 \\
\hline \multirow[t]{2}{*}{ Site 483} & All massive basalts & 13 & 3.44 & 1.15 & 6.2 & & & 70 & 39 & 78 & 1.12 & 0.08 & 0.93 & 234 \\
\hline & Fresh massive basalts & 4 & 1.31 & 1.32 & 3.4 & - & - & - & $24(2)$ & 56 & 0.98 & 0.05 & 0.94 & 192 \\
\hline \multirow[t]{2}{*}{ Site 483} & All pillow basalts & 12 & 10.4 & 0.88 & 29.3 & - & - & 85 & 43 & 94 & 1.05 & 0.18 & 1.02 & 218 \\
\hline & Fresh pillow basalts & 7 & 12.6 & 0.88 & 36.1 & - & -35 & 79 & $40(1)$ & 83 & 1.06 & 0.17 & 0.97 & 184 \\
\hline \multirow[t]{2}{*}{ Hole 485A } & All basalts & 23 & 3.95 & 1.33 & 6.2 & 28 & 33.5 & 71 & 44 & 95 & 1.42 & 0.085 & 0.92 & 325 \\
\hline & & & 2.04 & 0.32 & 3.7 & 16 & 12 & 39 & $13(13)$ & 37 & & & & 122 \\
\hline \multirow{2}{*}{ Hole 485A } & Fresh basalts & 4 & 4.8 & 1.44 & 6.9 & - & 33 & 49 & 32 & 65 & 1.21 & 0.11 & 0.97 & 180 \\
\hline & & & 1.9 & 0.15 & 3.6 & & 10 & 8 & & 4 & & & & \\
\hline
\end{tabular}

Note: Upper line = arithmetic mean, lower line = standard deviation; $N=$ number of samples; number in parentheses = number of samples is less than in Table 1; other symbols as in Table 1.

Consequently in diagrams of $J_{s}$ vs. $T_{\mathrm{C}}$ and $J_{s}$ vs. $H_{C R}$ for initially similar rocks, the data for fresh $\left(T_{\mathrm{C}}<200^{\circ} \mathrm{C}\right)$ and altered basalts should display different distribution patterns. Figures $3 \mathrm{~A}$ and $3 \mathrm{~B}$ show examples of the average $J_{s}, H_{C R}$, and $T_{\mathrm{C}}$ values for basalts from several different holes and for fresh basalts from the same holes. For the basalts from Holes 332A, 395, 396, 407, 409, $411,412,417,418$, and $428 \mathrm{~A}$, where single-phase oxidation of titanomagnetite is predominant (Hall and Ryall, 1977b; Pechersky et al., 1979; Johnson, 1979; Pechersky et al., 1980; Bliel and Petersen, 1977), $J_{s}$ decreases with increasing $T_{\mathrm{C}}$ and $H_{C R}$. In the case of oxidation to more than one phase, the $J_{s}$ vs. $T_{\mathrm{C}}$ and $J_{s}$ vs. $H_{C R}$ trends should be reversed, i.e., $J_{S}$ should increase with increasing $T_{\mathrm{C}}$ and $H_{C R}$.

Multiphase oxidation was observed in the massive basalts drilled on Leg 65 and in the massive basalts from Holes 417 and 418A on the Bermuda Rise. The presence of more than one oxidation phase in massive basalts explains the greater scatter of points for these basalts as compared to pillow lavas. This can also be seen in basalts from Sites 295 and 396 (Figs. 3C, 3D). The scatter of points for massive basalts cannot be explained solely by variations in titanomagnetite concentrations or the pillow basalts would give a much greater scatter of points since titanomagnetite concentrations in them vary more appreciably than in massive basalts.

In addition, an examination of thin sections of basalts from Leg 65 under an electron microscope (magnification $>4000 \times$ ) showed that thin lamellae no more than $0.2-0.5 \mu \mathrm{m}$ wide were present in titanomagnetite grains from some samples; these grains are frequently corroded and their edges are noticeably pitted. No thin lamellae were observed under an optic microscope.

Thus, the irregular behavior of magnetic properties in massive basalts from Holes 482 and $485 \mathrm{~A}$ appears to result from exsolution in titanomagnetite. This may be related to postmagmatic hydrothermal processes. Since the participation of water is known to result in only a single oxidation phase, this process must be dominated at first by heating. In Hole $482 \mathrm{~A}$, the temperature reached $80^{\circ} \mathrm{C}$ and a temperature of $150^{\circ} \mathrm{C}$ was measured in Hole $482 \mathrm{C}$. The magnetic changes increase from Hole 482 to 482D (Tables 1, 2), possibly reflecting an increase in the duration of heating. Basalts from Sites 417 and 418 were also affected by long heating at $40^{\circ} \mathrm{C}$ (Pertsev and Rusinov, 1980). In general, alteration of basalts increases with age, thereby suggesting that weathering by seawater contributes to the alteration of magnetic properties (Tables 1, 2). In the neighboring holes, 483 and $483 \mathrm{~B}$, however, one can see that alteration is proceeding selectively. Fresh rocks predominate in Hole 483, whereas rocks in Hole 483B have been altered. This is seen, too, in the basalts of Hole $485 \mathrm{~A}$, where the three lower magnetic units are altered, as compared to the upper unit.

As can be seen in Figure 1, the decrease in saturation magnetization, $J_{s}$, which occurs upon reheating in many of the basalts drilled on Leg 65 , takes place at about $200^{\circ} \mathrm{C}$. The reheating of Sample $482 \mathrm{C}-10-1,118 \mathrm{~cm}$ to $400^{\circ} \mathrm{C}$ for a period of 5 minutes, for example, results in an appreciable decrease of $J_{s}$ (up to $30 \%$ ), but the Curie point after such heating remains unchanged (Fig. 4A). The next heating (to $500^{\circ} \mathrm{C}$ for 3 minutes) leads to an abrupt change of the Curie point, but $J_{s}$ varies insignificantly (Fig. 4A). As can be seen in Figure 1 and Table 4 , the reheated samples from the holes drilled on Leg 65 vary for the most part from 120 to $220^{\circ} \mathrm{C}$, average $T_{\mathrm{C}}=180^{\circ}$, and thus approach values typical of primary titanomagnetite of ocean basalts (Johnson, 1979). In the subsequent heatings of samples to $600^{\circ} \mathrm{C}$ the curve $J_{s}$ vs. $T$ becomes practically reversible. Only the heating of crushed basalts in air at high temperatures causes titanomagnetite to oxidize to more than one phase. This is reflected in an increase in $J_{s}$ and the appearance of a new phase with a Curie temperature close to that of magnetite (Fig. 4A).

These results suggest resorbtion of exsolution lamellae in composed titanomagnetitic grains. The fact that such a process takes place in air at a rather low tempera- 

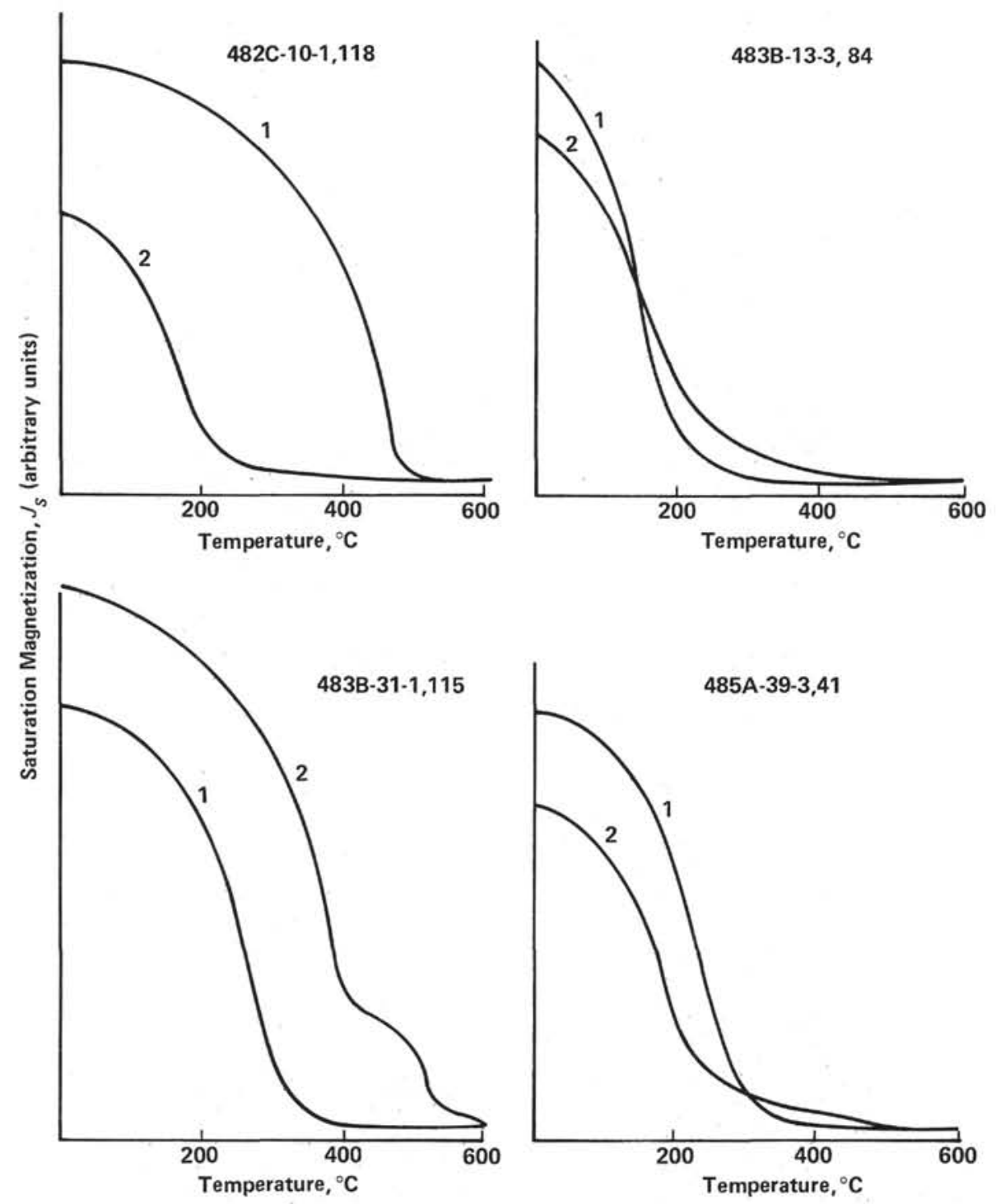

Figure 1. Saturation magnetization vs. temperature for representative basalts from Leg $65(1=$ first heating curve, 2 = second heating curve).

ture (about $500^{\circ} \mathrm{C}$ ) testifies to a very fine-scale exsolution structure. In thin sections of Sample $482 \mathrm{C}-10-1$, $118 \mathrm{~cm}$, thin lamellae less than $5 \mu \mathrm{m}$ long and $0.2-0.3$ $\mu \mathrm{m}$ wide are seen in some grains under an electron microscope. After heating in air up to $600^{\circ} \mathrm{C}$ these lamellae disappear. An identification of grain composition on the basis of the Curie points in the initial state $\left(T_{\mathrm{C}}\right.$ $\left.=460^{\circ} \mathrm{C}, \chi=0.2\right)$ and after resorbtion $\left(T_{\mathrm{C}}=180^{\circ} \mathrm{C}\right.$, $\chi=0.6$ ) indicated that the initial grains of titanomagnetite are exsolved into titanomagnetite with $\chi=0.2$ and ulvospinel. (Ulvospinel can be easily oxidized.) The ratio of titanomagnetite with $\chi=0.2$ to ulvospinel is $1: 1$. However, only rare lamellae are visible under an electron microscope. The grains composing ulvospinel appear to be so small that they are indistinguishable at a magnification of $8000 \times$. Similarity of values of $J_{s}$ at $-196^{\circ} \mathrm{C}$ before and after resorbtion (Fig. $4 \mathrm{~A}$, second and third curves, respectively) suggest exsolution. The absence of the Curie point of ulvospinel in Fig. 4A appears to be related to its low magnetization (Readman, 1978) and to the similarity of its Curie point to that of titanomagnetite with $\chi=0.2$.

Heating to $600^{\circ} \mathrm{C}$ does not always lead to complete or even partial resorbtion as can be seen in the case of several samples with more than one oxidation phase (Table 4). In addition to resorbtion, a high-temperature oxidation reaction takes place which results in the appearance of traces to appreciable amounts of a phase with $T_{\mathrm{C}} \geq 500^{\circ} \mathrm{C}$ (curve 3 in Fig. 4B).

The reason why $J_{s}$ decreases whereas $T_{\mathrm{C}}$ does not when a sample is heated to $400^{\circ} \mathrm{C}$ (Fig. 4A) is not clear. It may be related to the presence of small grains of maghemite. At temperatures of $400^{\circ} \mathrm{C}$ or less, the phase transformation of maghemite into hematite takes place, causing a decrease of $J_{s}$, but the primary magnetic phase remains almost unchanged. This is followed at higher 


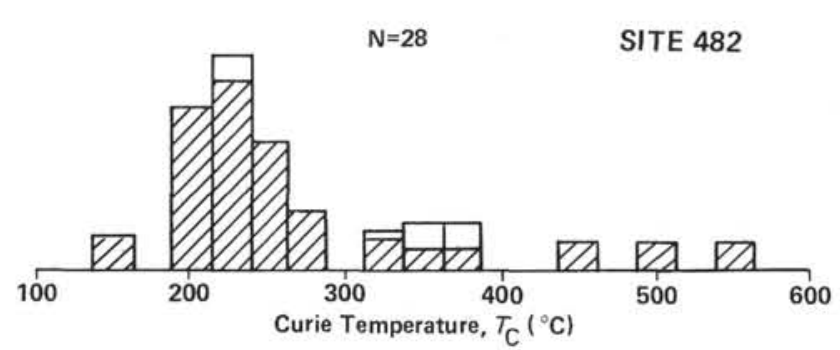

$\mathrm{N}=\mathbf{2 3} \quad$ SITE $\mathbf{4 8 3}$
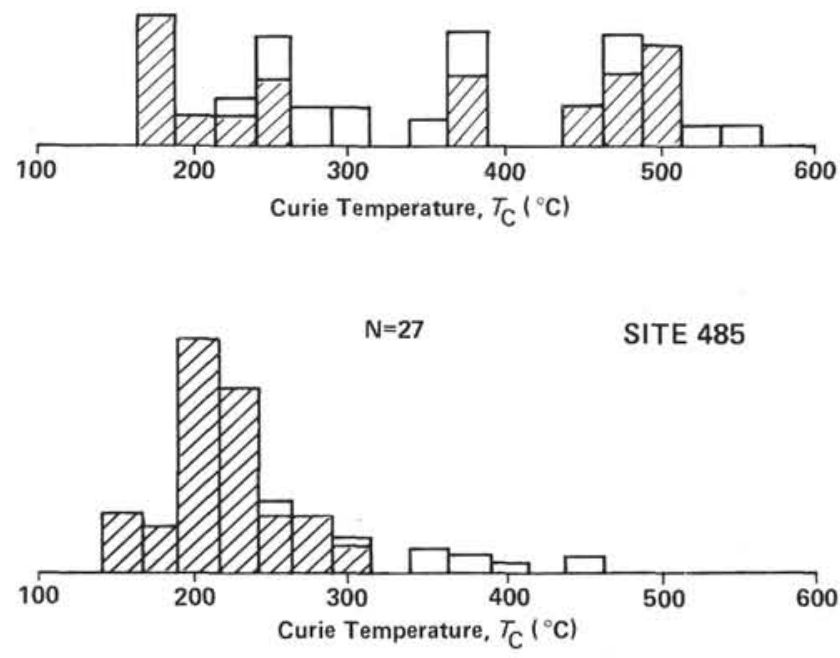

Figure 2. Curie temperature histograms for basalts from Sites 482 , 483 , and 485 ; shading indicates number of samples with only one phase.

Table 3. Average magnetic properties of magnetic units in Hole 485A.

\begin{tabular}{|c|c|c|c|c|}
\hline & Unit 1 & Unit 2 & Unit 3 & Unit 4 \\
\hline Core & 12 through 25 & 29 through $32-1$ & $32-3$ through 35 & 38 through 39 \\
\hline Polarity & Normal & Normal & Normal & Reverse \\
\hline $\begin{array}{l}\text { Petrographic } \\
\text { Changes }\end{array}$ & Fresh & $\begin{array}{l}\text { Slightly } \\
\text { Altered }\end{array}$ & $\begin{array}{l}\text { Slightly } \\
\text { Altered }\end{array}$ & $\begin{array}{l}\text { Slightly } \\
\text { Altered }\end{array}$ \\
\hline $\begin{array}{l}x_{,} \times 10^{-3} \text { gauss } / \mathrm{Oe} \\
J_{n} \times 10^{-3^{8}} \text { gauss } \\
Q_{n} \\
I^{\circ} \\
J_{s,}^{\circ} \text { emu/g } \\
J_{r s} / J_{s} \\
J_{s t} / J_{s} \\
T_{C},{ }^{\circ} \mathrm{C} \\
H_{C R}, \mathrm{Oe}\end{array}$ & $\begin{array}{l}1.445 \\
4.46 \\
6.6 \\
40.5 \\
1.47 \\
0.09 \\
0.95 \\
218 \\
84\end{array}$ & $\begin{array}{c}1.05 \\
3.46 \\
7.7 \\
21.5 \\
1.2 \\
0.09 \\
0.95 \\
430 \\
122\end{array}$ & $\begin{array}{c}1.53 \\
4.28 \\
4.4 \\
33 \\
1.6 \\
0.06 \\
0.88 \\
355 \\
100\end{array}$ & $\begin{array}{c}1.3 \\
0.78 \\
1.25 \\
-40 \\
1.36 \\
0.095 \\
0.84 \\
313 \\
79\end{array}$ \\
\hline
\end{tabular}

Note: Symbols as in Table 1.

temperatures by the resorbtion process described previously. The appearance of maghemite can be associated with hydrothermal processes.

As can be seen, magnetic properties of the basalts drilled on Leg 65 do not differ significantly from those of basalts of other regions of the World Ocean. Their main peculiarity consists in an unusual degree of multiphase oxidation and exsolution of titanomagnetite in the massive basalts. The predominance of magnetic phases with $T_{\mathrm{C}}<500^{\circ} \mathrm{C}$ suggests that this process occurs at low temperatures. In order to avoid confusion, we advise use of the term multiphase oxidation or exsolution, plus the addition of a temperature indicator (high-, low-, etc.) where this has been reliably confirmed. Neither the presence of lamellae nor a high $\mathrm{Cu}$ rie temperature $\left(T_{\mathrm{C}} \geq 500\right)$ provides unequivocal evidence of high-temperature oxidation. A Curie temperature of less than $500^{\circ} \mathrm{C}$, associated with other previously mentioned features, probably suggests low-temperature multiphase oxidation of titanomagnetite.

\section{PALEOMAGNETISM}

AF demagnetization was used to determine the stable direction of $J_{n}$. In the course of such demagnetization, the inclination, $I$, is commonly used. Therefore, while analyzing the changes of direction and the value of $J_{n}$, two components were measured: the maximum horizontal component $(X$ or $Y)$ and the vertical component $(Z)$.

Figure 5 presents the results of AF demagnetization of samples. Pillow basalt samples (Holes 483, 483B; Tables 1, 5) are characterized by high stability, whereas $60 \%$ of the massive basalts are unstable. Stability does not depend on the degree of alteration. In general, $\mathrm{MDF}_{n}$ $>\mathrm{MDF}_{s}$. According to the criteria of Lowrie-Fuller, this is primarily the effect of single domain grains. In unstable samples, a vertical component of $J_{n}$ (Fig. 5), readily removed by an alternating field of $25-50 \mathrm{Oe}$, is frequently observed (Hall and Ryall, 1977a; Petersen, 1978).

After AF demagnetization the cores from each hole except $485 \mathrm{~A}$ display only one polarity (Table 1,2 ): The cores from Site 482 are normally polarized, those from Site 483 are reversely polarized, and those from Cores 12 through 35 and 38 through 39 in Hole $485 \mathrm{~A}$ are, respectively, normally and reversely polarized.

As can be seen in Figure 6 and Table 1, the directions of the stable component of $J_{n}$ are variable and the inclinations fall into two rather distinct groups: the first group practically coincides with the inclination of the present-day geomagnetic dipole at the mouth of the Gulf of California $\left(\sim 40^{\circ}\right)$; the second group shows shallow inclinations (an average of $10^{\circ}$ for Sites 482 and 483 and $25^{\circ}$ for Hole $485 \mathrm{~A}$ ). Holes with a preponderance of stable samples $(483,483 \mathrm{~B}$, and $485 \mathrm{~A})$ show a more distinct bimodal distribution. Site 482 , which has a predominance of paleomagnetically unstable samples, gives a more ambiguous histogram. Samples with shallow and normal inclinations differ in the degree of alteration: the former are the more altered, their $J_{n}$ values are lower and their $H_{C R}, M D F$, and $T_{C}$ values higher (Tables 3, 5). In holes with a predominance of fresh rocks $(482 \mathrm{~B}$ and $483)$ the average inclinations are high $\left(39^{\circ}\right.$ and $-36^{\circ}$, respectively) whereas in the neighboring holes with more altered rocks $(482 \mathrm{C}, 482 \mathrm{D}$, and $483 \mathrm{~B})$ the inclinations are shallower $\left(16,22\right.$, and $-19^{\circ}$, respectively). In the upper part of Hole 485A the rocks are fresh and their average inclination is $40.5^{\circ}$; the lower rocks of the second unit are more altered and display an average inclination of $21.5^{\circ}$ (Table 3). In sites with normal and shallow inclinations, the first occupy, as a rule, the upper part of the hole (Table 1).

The well-pronounced bimodality in distribution of inclinations and the range of ages displayed by basalts with shallow inclinations suggests that the variations in 

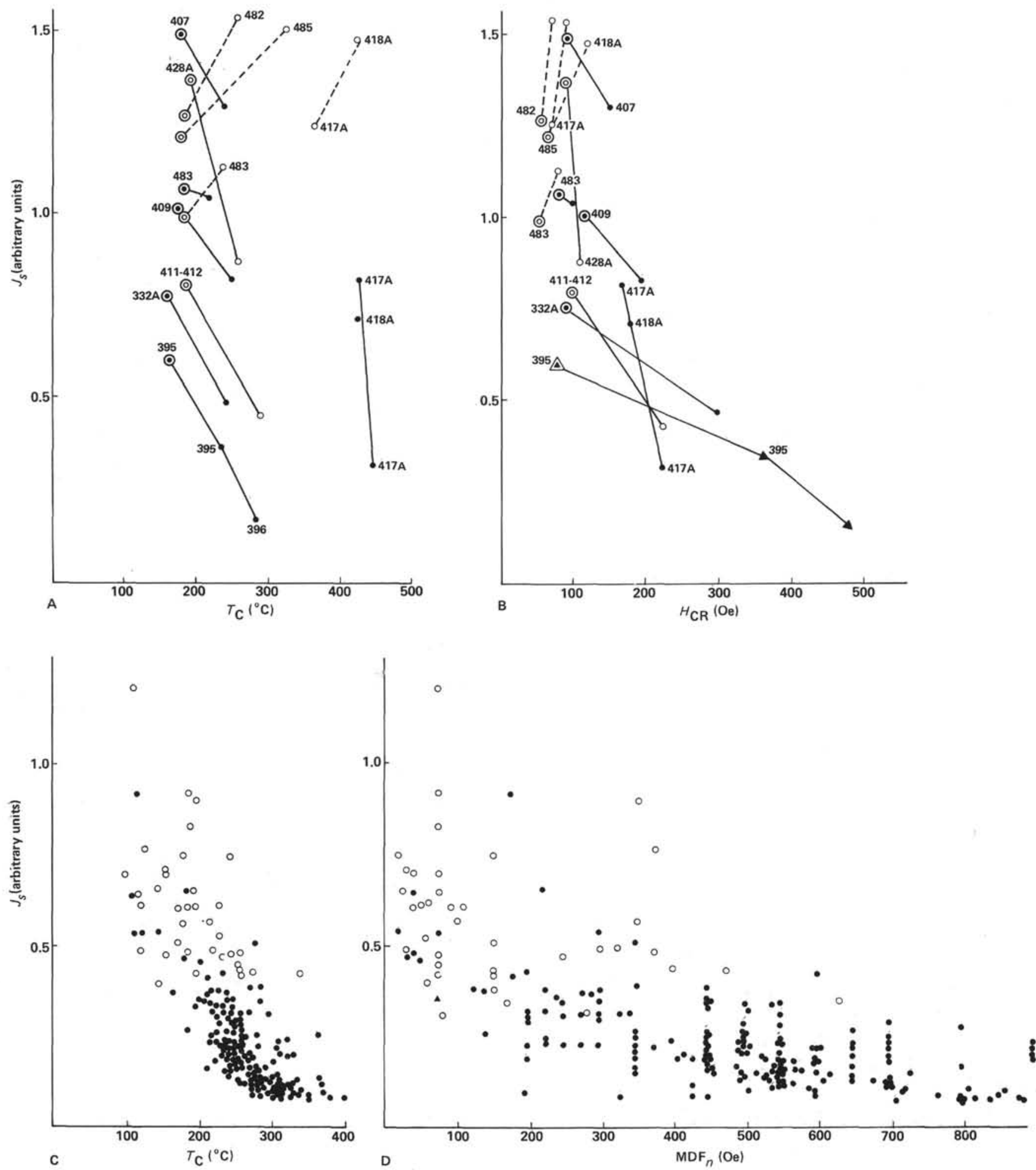

Figure 3. Variation of $T_{C}, H_{C R}$, and $\mathrm{MDF}_{n}$ vs. $J_{S}$ and alteration. (Open circles = massive basalts, solid circles = pillow basalts, double circles $=$ fresh basalts. A. $T_{C}$ vs. $J_{S}$; tie lines connect average values for fresh and altered basalts or average values for related sites. B. $H_{C R}$ vs. $J_{S}$; tie lines connect average values of fresh and altered basalts or average values for related sites. C. $T_{C}$ vs. $J_{S}$ for basalts from Sites 395 and 496 . D. $\mathrm{MDF}_{n}$ vs. $J_{s}$ for basalts from Sites 395 and 396. 


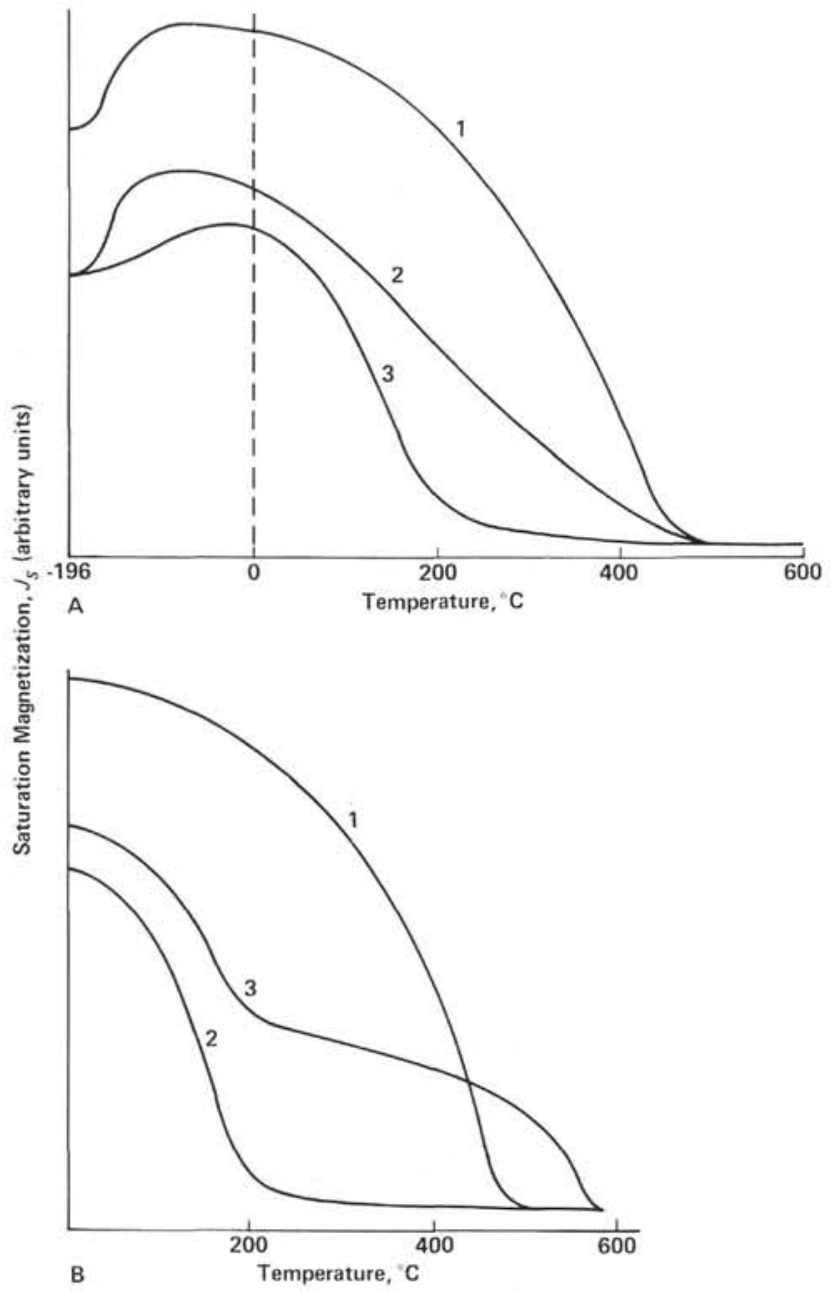

Figure 4. Saturation magnetization vs. temperature in Sample 482C$10-1,118$ over several heating cycles. $(\mathrm{Al}=$ first heating curve; $\mathrm{A} 2$ = heating curve after initial heating to $400^{\circ} \mathrm{C}$ for $5 \mathrm{~min}$.; $\mathrm{A} 3=$ heating curve after initial heating to $500^{\circ} \mathrm{C}$ for $3 \mathrm{~min}$.; $\mathrm{B} 1=$ first heating curve; $\mathrm{B} 2=$ heating curve after initial heating to $600^{\circ} \mathrm{C}$; $\mathrm{B} 3$ = heating curve for powder after initial heating of massive sample to $600^{\circ} \mathrm{C}$.

inclination are not related to variations of the geomagnetic field.

Thus, the appearance of shallow inclinations in the basalts under study is not connected with the history of the geomagnetic field. The relation of shallow inclinations and alteration, however, is not likely to be direct. Since the basalts studied are young, alteration should not result in appreciable changes in inclination from those of the recent geomagnetic field. The following considerations also rule against a direct relation between shallow inclinations and alteration of basalts: Among pillow basalts, normal and shallow inclinations are present in roughly equal proportions in both fresh and altered samples (Tables 1 and 5). It is also known that during low-temperature oxidation of titanomagnetite and magnetite grains, the directions of remanent magnetization remain unchanged (Marshall and Cox, 1971; Hall and Ryall, 1977b; Livshits et al., 1971). Hence, shallow inclinations in pillow basalt samples from Site 483 are
Table 4. Curie temperatures of basalts drilled on Leg 65 .

\begin{tabular}{|c|c|c|}
\hline $\begin{array}{c}\text { Sample } \\
\text { (level in } \mathrm{cm})\end{array}$ & $\begin{array}{c}T_{\mathrm{C}}, \text { First } \\
\text { Heating } \\
\left({ }^{\circ} \mathrm{C}\right)\end{array}$ & $\begin{array}{c}T_{\mathrm{C}}, \text { Second } \\
\text { Heating } \\
\left({ }^{\circ} \mathrm{C}\right)\end{array}$ \\
\hline 482B-12-3, 17 & 160 & 130 \\
\hline $482 \mathrm{~B}-15-3,42$ & 190 & $170(90), 500$ \\
\hline $482 \mathrm{~B}-20-2,35$ & 285 & $200(80), 540$ \\
\hline $482 \mathrm{~B}-22-1,73$ & 230 & 170 \\
\hline $482 C-10-1,118$ & 450 & 180 \\
\hline $482 C-13-2,60$ & $300(10), 510$ & 510 \\
\hline $482 C-15-4,139$ & 250 & 210 \\
\hline $482 \mathrm{D}-10-2,85$ & 360 & 150 \\
\hline $482 \mathrm{D}-9-1,115$ & 540 & $120(50), 570$ \\
\hline $483-15-1,110$ & 200 & 160 \\
\hline $483-17-2,108$ & 225 & 285 \\
\hline $483-26-3,68$ & $150 ?(15), 240(50), 330$ & $160(60), 380(30), 530$ \\
\hline 483B- 12,172 & 250 & $190(60), 350(25), 550$ \\
\hline 483B-13-3, 84 & $200(90), 330$ & $165(70), 350(15), 460$ \\
\hline $483 \mathrm{~B}-27-2,25$ & $280(90), 370$ & $200(90), 300$ \\
\hline 483B-32-1, 115 & 290 & $350(60), 500$ \\
\hline $485 \mathrm{~A}-14-1,40$ & 180 & $135(80), 520$ \\
\hline $485 \mathrm{~A}-17-1,43$ & $260(60), 520$ & $210(50), 380(30), 530$ \\
\hline $485 \mathrm{~A}-25-1,108$ & $230(75), 380$ & 180 \\
\hline $485 \mathrm{~A}-31-1,94$ & $200(10), 365(40), 540$ & $300(85), 520$ \\
\hline $485 \mathrm{~A}-32-4,58$ & 520 & $340(20), 520$ \\
\hline $485 \mathrm{~A}-34-2,60$ & $260(70), 400$ & $200(80), 400$ \\
\hline $485 A-35-5,105$ & 240 & $220(80), 520$ \\
\hline
\end{tabular}

Note: Value in parentheses = percentage of magnetic phase with the Curie temperature shown.

not directly connected with oxidation of titanomagnetite grains. The low inclinations observed in many of the basalts drilled on Leg 65 may thus result from a combination of alteration and tectonic rotation.

\section{CONCLUSION}

The magnetic properties of basalts from Leg 65 indicate a wide distribution of multiphase, apparently lowtemperature oxidation and decomposition of titanomagnetite; this is especially pronounced in massive basalts. The main cause of this phenomenon may be long heating of rocks at temperatures of approximately $100^{\circ} \mathrm{C}$ or below. Low inclinations in the deeper, more altered sections of the holes suggest that tectonic rotation has taken place at several of the sites.

\section{REFERENCES}

Ade-Hall, J. M., Johnson, H. P., and Ryall, P. J.C., 1976. Rock magnetism of basalts, Leg 34. In Yeats, R. S., Hart, S. R., et al., Init. Repts. DSDP, 34: Washington (U.S. Govt. Printing Office), 459-468.

Bleil, U., and Petersen, N., 1977. Magnetic properties of basement rocks, Leg 37, Site 332. In Aumento, F., Melson, W. G., et al., Init. Repts. DSDP, 37: Washington (U.S. Govt. Printing Office), 446-456.

Burakov, K. S., 1977. Thermomagnetometer. Izv. Akad. Nauk SSSR. Ser. Phizika semli, No. 5. (In Russian)

Hall, J. M., and Ryall, P. J. C., 1977a. Paleomagnetism of basement rocks, Leg 37. In Aumento, F., Melson, W. G., et al., Init. Repts. DSDP, 37: Washington (U.S. Govt. Printing Office), 425-446. 1977b. Rock magnetism of basement rocks, Leg 37. In Aumento, F., Melson, W. G., et al., Init. Repts. DSDP, 37: Washington (U.S. Govt. Printing Office), 489-502.

Johnson, H. P., 1978. Rock magnetic properties of igneous rock samples-Leg 45. In Melson, W. G., Rabinowitz, P. D., et al., Init. Repts. DSDP, 45: Washington (U.S. Govt. Printing Office), 397-406. 
1979. Magnetization of the oceanic crust. Rev. Geophys. Space Phys., 17: No. 2.

Johnson, H. P., and Hall, J. M., 1978. A detailed rock magnetic and opaque mineralogy study of the basalts from Nazca Plate. Geoph. J. Roy. Astr. Soc., 52:45-64.

Livshits, L. D., Pechersky, D. M., and Trukhin, V. I., 1971. Increase of remanent magnetization in heating of wustite. Izv. Akad. Nauk SSSR, Ser. Phizika Zemli, No. 8. (In Russian)

Marshall, M., and Cox, A., 1971. Effect of oxidation on the natural remanent magnetization of titanomagnetite in suboceanic basalt. Nature, 40:28-31.

Pechersky, D. M., Tikhonov, L. V., and Rusinov, V. L., 1980. Magnetism of basalts of Bermuda Rise. Reshenie Geophizicheskikh zadach Geomagnitnymi Metodami. (In Russian)

Pechersky, D. M., Tikhonov, L. V., and Zolotarev, B. P., 1979. Magnetism of basalts of Atlantic. Izv. Akad. Nauk., Ser. Phizika Zemli, No. 12. (In Russian)

Pertsev, N. N., and Rusinov, V. L., 1980. Mineral assemblages and processes of alteration in basalts at Deep Sea Drilling Project Sites
417 and 418. In Donnelly, T., Francheteau, J., Bryan, W., Robinson, P., Flower, M., Salisbury, M., et al., Init. Repts. DSDP, 51, 52, 53, Pt. 2: Washington (U.S. Govt. Printing Office), 1219-1242.

Petersen, N., 1979a. Glomar Challenger drillings: The magnetic field produced by the drill and drill string. In Dmitriev, L., Heirtzler, J., et al., Init. Repts. DSDP, 46: Washington (U.S. Govt. Printing Office), 377-378.

, 1979b. Rock- and paleomagnetism of basalts from Site 396B, Leg 46. In Dmitriev, L., Heirtzler, J., et al., Init. Repts. DSDP, 46: Washington (U.S. Govt. Printing Office), 357-362.

Readman, R. N., 1978. Magnetic properties of ulvospinel, Phys. Earth Planet. Inter., 16:196-199.

Skovorodkin, Yu. P., Burakov, K. S., and Bezuglaya, L. S., et al. 1970. Device for studying magnetic properties of mountain rock samples at various pressures and temperatures. Tezisy dokladov VIII Konferentsii po voprosam postoyannogo polya, magnetizma gornykh porod i paleomagnetizma, No. 2, M. (In Russian)

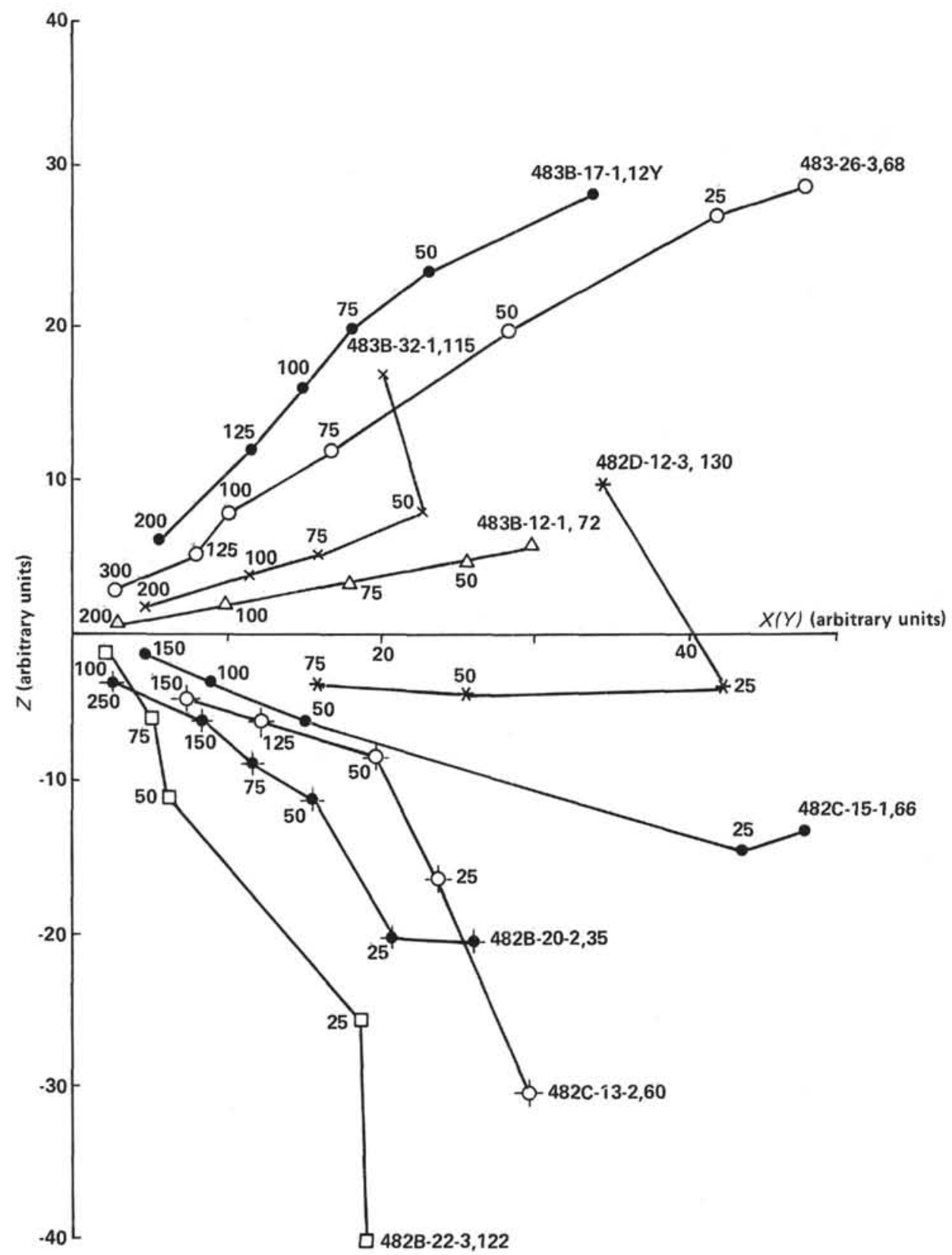

Figure 5. Examples of AF-NRM demagnetization curves. Values on curves represent alternating field intensities in Oe. 
Table 5. Average magnetic and paleomagnetic properties of Leg 65 basalts with normal and shallow inclinations.

\begin{tabular}{|c|c|c|c|c|}
\hline \multirow{2}{*}{$\begin{array}{c}\text { Relative Stability of } I_{n} \\
\text { during AF Demagnetization } \\
{ }^{4} \text { Inclination }\end{array}$} & \multicolumn{2}{|c|}{ Stable } & \multicolumn{2}{|c|}{ Unstable } \\
\hline & $|I| \geq 30^{\circ}$ & $|I|<30^{\circ}$ & $|I| \geq 30^{\circ}$ & $|I|<30^{\circ}$ \\
\hline Petrography & & & & \\
\hline $\begin{array}{l}\text { Aphyric basalts, number } \\
\text { of samples }\end{array}$ & 3 & 9 & 11 & 4 \\
\hline $\begin{array}{l}\text { Porphyritic basalts, number } \\
\text { of samples }\end{array}$ & 13 & 7 & 6 & 11 \\
\hline Pillow basalts & 6 & 5 & 0 & 0 \\
\hline Massive basalt flows or sills & 16 & 16 & 17 & 15 \\
\hline Altered & 6 & 9 & 5 & 7 \\
\hline Fresh & 10 & 7 & 12 & 8 \\
\hline$J_{n}\left(\times 10^{-3}\right.$ gauss $)$ & 8.3 & 5.9 & 4.4 & 3.3 \\
\hline$J_{S}(\mathrm{emu} / \mathrm{g})$ & 1.3 & 1.2 & 1.4 & 1.3 \\
\hline$J_{r s} / J_{s}$ & 0.13 & 0.14 & 0.07 & 0.07 \\
\hline$H_{C R}(\mathrm{Oe})$ & 88 & 110 & 71 & 78 \\
\hline $\mathrm{MDF}_{n}(\mathrm{Oe})$ & 69 & 99 & 45 & 60 \\
\hline $\mathrm{MDF}_{s}(\mathrm{Oe})$ & 43 & 50 & 33 & 38 \\
\hline$T_{\mathrm{C}}\left({ }^{\circ} \mathrm{C}\right)$ & 250 & 320 & 260 & 270 \\
\hline$J_{s t} / J_{s o}$ & 0.93 & 0.99 & 0.86 & 0.86 \\
\hline $\begin{array}{l}\text { Reversed polarity } J_{n} \text {, number } \\
\text { of samples }\end{array}$ & 9 & 5 & 4 & 3 \\
\hline $\begin{array}{l}\text { Normal polarity } J_{n} \text {, number } \\
\text { of samples }\end{array}$ & 7 & 11 & 13 & 12 \\
\hline Total number of samples & 16 & 16 & 17 & 15 \\
\hline
\end{tabular}

Note: In case of shallow inclinations, the polarity $J_{n}$ may be erroneous. Symbols as in Table 1.
SITE 482 (N)

$\mathrm{N}=\mathbf{2 4}$

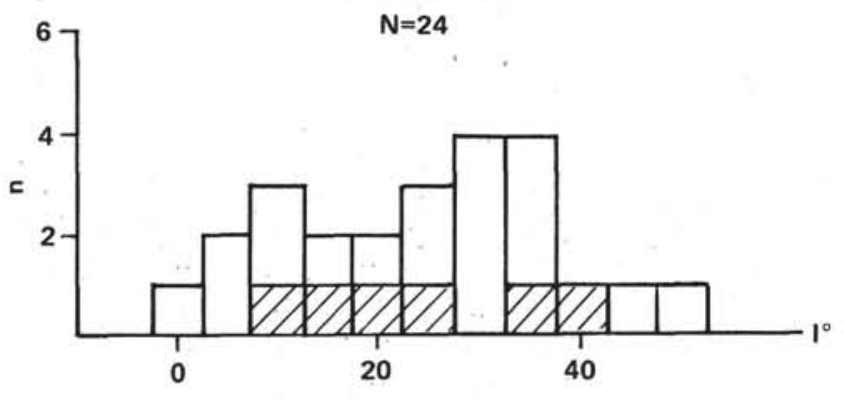

SITE 483 (R)

$\mathrm{N}=\mathbf{2 0}$

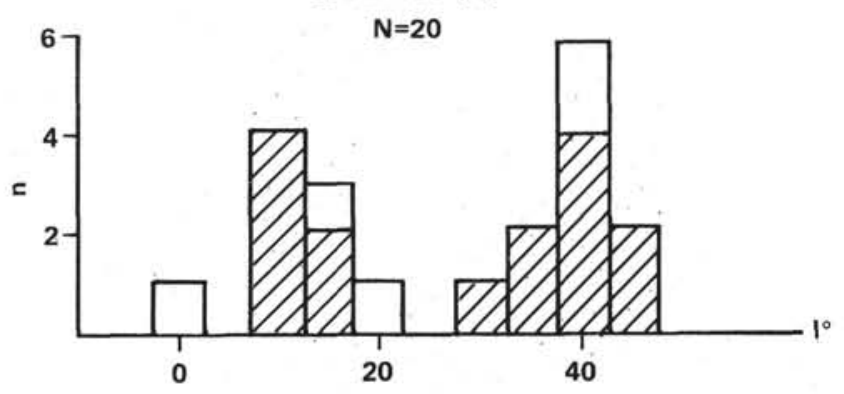

SITE 485 (N,R)

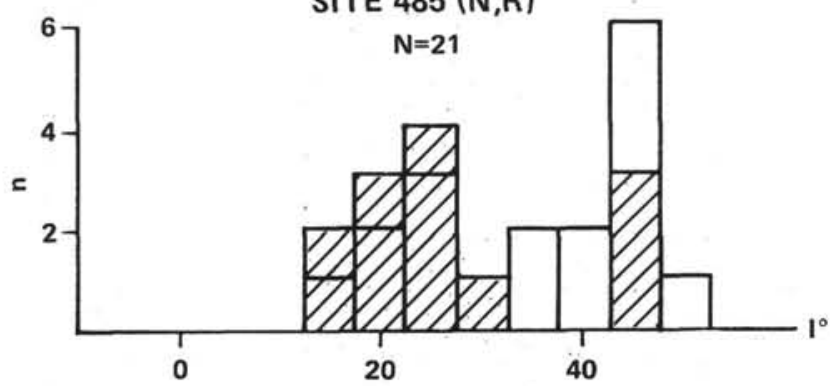

Figure 6. Histograms of inclinations for Leg 65 basalts, Sites 482 , 483 , and 485 . (Shading $=$ stable; open $=$ unstable.) 